\title{
THE ASSOCIATION BETWEEN PATIENT SATISFACTION AND LOYALTY AT COMMUNITY HEALTH CENTER IN NGLETIH, KEDIRI, EAST JAVA
}

\author{
Sandu Siyoto, Mareta Dewi Ariyanti \\ Institute of Health Science Surya Mitra Husada, Kediri
}

\begin{abstract}
BACKGROUND: A hospital, community health center, doctor's clinic, cannot survive without retaining patients. Otherwise it will rifle through new patients until no more exist nearby. As evidence from the US has shown, the average practice loses $50 \%$ of its patient base every five years. It costs 5 to 10 times as much money to secure a new patient than to retain an existing one. Retaining customers therefore is beneficial in the short and long run. This study aimed to investigate how patient saticfaction affects propensity to return, i.e. loyalty.

SUBJECT AND METHODS: This was a cross sectional study conducted in Kediri district, East Java. A sample of 157 patients who were not entitled for the National Health Insurance (Jaminan Kesehatan Nasional) scheme in Kediri, East Java, was selected by random sampling. The dependent variable was propensity to return (loyalty). The independent variable was satisfaction. The data was analyzed using Odds Ratio (OR) and ChiSquare.

RESULT: There was a very strong and statiscally significant link between saticfaction and loyalty. Patients who were satisfied with the health care provided were 104 times as many to return than those who were not satisfied $(\mathrm{OR}=103.90 ; 95 \% \mathrm{CI}=28.74$ to $375.40 ; \mathrm{p}<0.001)$.

CONCLUSION: The indicators of patient satisfaction are officers' reliability, responsiveness, assurance, tangibles, and empathy. And indicators of patient are loyalty, namely in terms of the frequency of visits, not easily switch to another clinic, recommend to others, to make a complaint, and defense. By providing services that meet patient satisfaction indicators will directly be able to create a loyal patient.
\end{abstract}

Keywords: Satisfaction, Loyalty 